\title{
Blending Construction In English Foods And Beverages In Indonesia: Linguistics And Cultural Views
}

\author{
Sulhizah Wulan Sari ${ }^{1}$, Rini Martiwi ${ }^{2}$ \\ ${ }^{1,2}$ Universitas Bina Sarana Informatika \\ e-mail: sulhizah.szw@bsi.ac.id ${ }^{1}$, rini.ntw@bsi.ac.id ${ }^{2}$

\begin{tabular}{ccc}
\hline Diterima & Direvisi & Disetujui \\
$10-08-2020$ & $30-08-2020$ & $21-09-20$ \\
\hline
\end{tabular}

\begin{abstract}
This research investigates the composing of the portmanteau word in food and beverage names or brands in Indonesia, referring to the types of blending in the source word proposed by John Algeo. Based on the linguistic and cultural view, the fact shows the name or brand of foods and beverages carry their characteristics, identities, and motives in its usage. The descriptive qualitative method is applied in this study by collecting the English food and beverage name or brand taken from offline and online searching. Offline data is searched by the observation in Mall, shop, and restaurant. Online data is gained from the internet web starting from March up to May. The collected data from online and offline is tabulated all together into blending types then shorted the source word to reveal the structure of the word class and its phonology. This study brings out the blending process results into four categories: Complex Clipped Word, Back Clipped Word, The combination of Fore and Back Clipped Word, and Phonemic Overlapping and Clipping. The culture in the portmanteau words (the English foods and beverages name) is revealed in the origins of the source words (Borrowing word). They are 13 borrowed words composed of the name of English foods and beverages. This study is important to develop the fundamental aspects of blending in English food and beverages in Indonesia by looking at the linguistic view and its relation to cultural view.
\end{abstract}

Key Word: English Blending, Foods and Beverages, Linguistic and Cultural View

\begin{abstract}
Abstrak - Penelitian ini bertujuan untuk menyelidiki susunan kata portmanteau dalam nama atau merek makanan dan minuman di Indonesia yang mengacu pada jenis blending menurut John Algeo. Berdasarkan pandangan linguistik dan budaya, fakta menunjukkan bahwa nama atau merek makanan dan minuman membawa karakteristik, identitas, dan motif dalam penggunaannya. Metode deskriptif kualitatif diterapkan dalam penelitian ini dengan mengumpulkan nama atau merek makanan dan minuman bahasa Inggris yang diambil dari pencarian offline dan online. Data offline dikumpulkan melalui pengamatan di Mall, toko, dan restoran. Data online diperoleh dari web internet dimulai pada bulan Maret hingga Mei 2020. Data yang dikumpulkan dari online dan offline diletakkan ke dalam tabel dan diklasifikasikan ke dalam jenis blending kemudian dipilih bentuk kata sumber untuk mengungkapkan struktur kelas kata dan fonologinya. Hasil dari penelitian menunjukkan proses blending ke dalam 4 kategori: Complex Clipped Word, Back Clipped Word, The combination of Fore and Back Clipped Word, and Phonemic Overlapping and Clipping. Budaya yang terkandung dalam kata-kata portmanteau (nama makanan dan minuman bahasa Inggris) terdapat dalam asalusul kata-kata sumber (Borrowing word). 13 kata pinjaman yang terdiri dari nama makanan dan minuman bahasa Inggris. Penelitian ini penting untuk mengembangkan aspek-aspek mendasar dari blending dalam makanan dan minuman bahasa Inggris di Indonesia dengan melihat pandangan linguistik dan hubungannya dengan budaya.
\end{abstract}

Kata kunci: Blending Bahasa Inggris, Makanan dan Minuman, Linguistik dan Pandangan Budaya

\section{INTRODUCTION}

The use of blending concepts on brand or names or food and beverage in Indonesia has been widely applied and found. It spreads in various media, both print media (newspapers, magazines, brochures, pamphlets) and electronic media (computers, TV, radio, and online form). According to (Člić 2015), the emergence and development of blending are caused by social life trends such as finance, computer technology, music, fashion, crime, education, advertisement, etc. Those fields require new words than those already existed in the dictionary or reference. The limitations of dictionaries and references in storing words cannot be adjusted, conditioned, and used with the concept of the needed word in every field and sectors like business, education, government, tourism, 
advertisements, and many more. Hence, he assumed that it is possible to see that blending is mostly used and applied only to the generation and professional classes. So the rise of blending usage happens continuously, and its existence cannot be separated from humans' daily lives in linguistics features and conditional usage.

Referring to the cultural view, foods and beverages bring and introduce their original culture. For example, the hamburger's food name derives from the city of Hamburg in German (Algeo, 2010), or Boba (Bubble drink) comes from Chinese. Besides, it can represent the region's identity or country where foods and beverages products are made. It characterizes a specific and cultural identity that is packaged in the name of foods and beverage products, brand, or trademarks, such as the name of Javapuccino (Java + Cappuccino), Solopuccino (Solo + Cappuccino) (Purwani, 2013). According to the researchers, the names of beverages (Solocapuccino and Javacapuccino) show the identity of its region and show the experience of traditional culture mixing with modern foreign culture using beverages' taste, style, and brand.

Furthermore, the word of cappuccino at the same time brings an internalized global modern ideology through Europe and its contingents. Cappuccino has the synonym meaning as 'kopi' in Indonesia. When the two words' Java or Solo' and 'Cappuccino' are combined, the beverage words coin a representation of mixing traditional and modern styles.

Lewis Carroll created the origin of blending or portmanteau word in 1882 (Hosseinzade, 2014). A portmanteau comes from French 'Porter' means 'to carry,' and the word 'Manteau' means 'Mantle' (Algeo, 2010). He explains that the term can be interpreted as a large suitcase. It has two halves and can be opened like a book on a center hinge. So blending or the portmanteau word is a widespread phenomenon in producing new words, and it is common to use. This is marked by the start of many people who use the process of mixing words. The history of blending usage can be traced in Shakespeare's time, and it has been studied since the twentieth century, but Algeo states that the definitions of blending and its categories have not yet been set at that time (Rini \& Moehkardi, 2019). Further, in the United Kingdom era, when the UK's exit on the $23^{\text {rd }}$ of June 2016 from the European Union Society gave rise to blend the term. It brings out the new term 'Brexit' and stands for (Britain Exit), which means the British came out (Giyatmi; Wijayava; Arumi, 2018).

Meanwhile, according to (Giyatmi; Wijayava; Arumi, 2018), they confirm that the use of the blending concept in Indonesia is expected to emerge in early 2000. When the term 'netizens' introduced to the public and the rapid development of the internet world, that term emerged to refer to the internet users in cyberspace. Netizens are blends that originate from the Internet and Citizen. Afterward, many blending names are created to fulfill the virtual needs. The virtual world provides many new terms using blending arrangements, such as 'Tweeple' (twitter people), 'Twebay' (twitter buy), and 'Trentop' (trending topic). Thus, the development and formation of new vocabulary in blending can be categorized as productive, creative, and communicative word formation and language. As (Giyatmi; Wijayava; Arumi, 2018) said that blends are very productive in creating and shaping the existing word and new vocabulary.

In this case, the new language or vocabulary is produced in blending for the names or brands of foods and beverages that contain various components. The components are interrelated in the formation of new language and vocabulary meanings. The components in blending words relate to culture, identity, economy (including commodity, creativity, marketing strategy), and communication (producing meaning and marketing as a strategy to sell the product).

The reasons for conducting this research and analysis of blending, particularly on English foods and beverages, are taken from many assumptions and facts. The first reason is based on the use of the English language as a foreign language, and it is not the mother tongue of Indonesian. Indonesian considers English as something that comes from foreign and has a particular trait, while the Indonesian language is easy to remember, easy to hear, and familiar with them. This fact is shown in the market place like cafés, shops, restaurants, and shopping centers both in Malls or traditional concepts which use an English-language brand and name. Thus, the use of food and beverage names in English has become familiar with Indonesia's people. This fact is cited in (Purwani 2013) that many Indonesian consumers come from businesses field, making their food and beverage products' names or trademarks using the English language.

The second reason is that using English in the names or brands of food and beverage products is used as a communication tool. (Purwani, 2013) asserts that English is used in various forms of communication, including advertisements. Advertising is made to impress the audience through the use of the English language. In turn, its usage endeavors to be interesting. (Purwani, 2013) explains that this condition is caused by many foreign (English) vocabulary terms borrowed by Indonesian. Rodliah and Nafisa (Purwani, 2013) add that foreign language is adopted and borrowed due to the absence of English equivalent in Indonesian. So blending is 
considered to be something practical, easy, and appropriate to Indonesian.

Besides that statement, advertising language development appears like an attraction for economic goals (Lestari, 2017). English brand names become an excellent business competition tool, especially blending in many media such as newspaper ads, magazines, brochures, posters, etc. According to (Čolić 2015), technology in the modern era provides many rules of communication. It is used to serve supporting needs for creating new words, and it has existed as a reflection of economics and linguistic creativity. Both the linguistic and economic creativity in creating new words are shown in advertising as a marketing strategy. As (Čolić 2015) added, the desire to shorten certain expressions in the name of the product is the motive of marketing's popularity. Thus, language can be derived from the basis and motives for the growth of language itself. In general, people understand that the function of language is used as a communication tool. Keraf (Lestari, 2017) stated that language consists of one of four things; language as a means of self-expression, communication, carrying out social integration and adaptation and establishing social control. Therefore, the language function in blending food and beverages is a tool for communication and the attraction for the customer to buy the product.

The last reason is the existence of an English brand image in the name of food and beverages. Based on Setiadi's opinion (Lestari, 2017), the brand image represents the brand's overall perception, and it is formed from information and experience. The image of the name or brand is related to the attitude in the form of beliefs and preferences towards the product or brand's name. Consumers who have a positive image of a brand will be more likely to make a purchase. Sequentially, advertising defines the image of a specific obtained meaning when people use the product (Lestari, 2017).

On the other hand, linguistics views blending (the portmanteau word) relating to morphology to examine word-formation. According to Katamba, morphology is studying the arrangements in forming words (Sundari, 2008). So it is included in the linguistics field. Generally, blending consists of two words or more. The composition of blending is applied in many languages such as Indonesia, English, Paris, Spanish, Japanese, Turkish, and others. The example, two words of either domestic or foreign origins are merged like the combination of words between Croatian and English language 'Coolinarika, Podroom, and Booksa' (Čolić, 2015). Those blending words have witty expressions.

Cook \& Stevenson (Fajrin, 2017) explains more detail about blending. The formation of a new word can be created by combining two or more words, and the result of its combination distributes the new word and meaning; the example in the English words "Breakfast" and "Lunch" can be fused to form the new word "Brunch". So blending is realized to form new words that are very productive (Gries in Komara, 2015). (Algeo in Shaw, 2013) adds that blending occurs due to various factors as part of morphology. It can be a distinct process from derivation with bound morphemes. When studying the formation of words in morphology, it is closely related to how the words are formed from the smallest segments or referred to as morphemes. A morpheme is understood as the smallest meaningful unit (Meyer in Komara, 2015).

Furthermore, Algeo (Shaw, 2013) presents three types in blending formation. The first type is the phonemic overlapping. It occurs when a syllable or part of a syllable is shared between two words. The second type is the clipping. It is applied when the shortening of one or two words is compounded and produces the new word. The third is phonemic overlapping and clipping. The third way is to shorten two words or more and share syllable then compound it. (Hosseinzade, 2014) adds that the phonemic overlapping can function when a syllable or part of a syllable is shared between two words then coins new meaning or word.

The three classifications of the blending proposed by Algeo are related to the structural categories. It deals with how blends are formed. They are blends with overlapping, blends with clipping, clipping at morpheme (syllable) boundaries, and blends with clipping and overlapping (Rini \& Moehkardi, 2019). The clipping process is divided into back clipping, fore clipping, middle clipping, and complex clipping. Plag in (Kjellander, 2015) assumes that complex clippings are a type of blend. It entails the final clipping of both source words.

Those definitions of blending are valued not only from the nature of its term but also from many aspects, both cultural and linguistic view. Hence, it can be assumed that this study is essential to be conducted. It is useful to add sources of blending in Indonesia using the English language and add culinary vocabulary as a way to obtain different findings for the development of the concept of blending. The researchers consider the previous research that has conducted by several researchers like (Komara, 2015), (Sundari, 2008), (Giyatmi; Wijayava; Arumi, 2018), and many others. Their concerns of research emphasize the language aspects of blending formation in linguistics view, and they are also many pieces of research examine in cultural view. However, the combination of language and culture analysis is still small, so there is a need to add references related to both relations to enrich the findings and data collection. The previous research similar to this research has been made in studies such 
as in (Fatmaway \& Anggraini, 2019) for the cultural view on borrowing words and also the research of (Hosseinzade 2014) in categorizing the types of blending proposed by Algeo. As a final point, this research needs to be studied to find out how the English names of food and beverage are formed using the blending proposed by Algeo? The second question is how the culture in the portmanteau words (the foods and beverages) is revealed.

\section{METHOD}

A descriptive qualitative method is applied to this research. It describes, explains, and investigates data using the concept and discussion of the collected data comprehensively. The research instruments are the names or brands of foods and beverages that exist in Indonesia. Besides, the procedures of collected data use two ways, online and offline searching. It means that the blending words are searched via offline (observation) and online (website). The offline source is conducted by visiting several malls spread in Indonesia and observing shops' food and beverage that use blending. When the data is found, it is written and captured. At the same time, searching is led by looking for the name of foods and beverages via the website or the internet. The time of collecting data begins from March up to May 2020.

In succession, blending words are analyzed using the types of blending proposed by John Algeo to know their formation and the process of making the new word or vocabulary in the tabulated form. The selection of Algeo's blending types is applied to focus more on applying existing theory because his types focus on structural classification of the blend. Then, to find the source word of the blending, the researchers use a dictionary-like Merriam Webster (https://www.merriam-webster.com/), Oxford, and the product's reference from the internet. The last procedure is sorting out the name or brand of foods and beverages into blending types and the appropriate words. The researchers use the color or mark and apply it in the tabulated data (Showing the description of the first research question). The second question is answered by looking at the origins of the source word in the portmanteau of foods and beverages.

\section{FINDING AND RESULTS}

\section{How are the English names of food and beverage formed using blending types which are proposed by Algeo?}

The first question is answered using the analysis of the obtained data from online and offline.
It shows that they are 59 of the portmanteau words can be classified into the classification of blending based on Algeo's types as described in the following table:

Table 1 Complex Clipped Word

\begin{tabular}{|c|c|c|c|c|}
\hline \multirow[b]{2}{*}{ No } & \multirow{2}{*}{$\begin{array}{c}\text { The } \\
\text { Portmant } \\
\text { eau } \\
\text { Word }\end{array}$} & \multicolumn{3}{|c|}{ Blending Formation } \\
\hline & & $\begin{array}{c}\text { Source of } \\
\text { the } 1^{\text {st }} \\
\text { Word }\end{array}$ & $\begin{array}{c}\text { Source } \\
\text { of the } \\
2^{\text {nd }} \\
\text { Word }\end{array}$ & $\begin{array}{c}\text { Source } \\
\text { of the } \\
3^{\text {rd }} \\
\text { Word }\end{array}$ \\
\hline 1 & $\begin{array}{l}\text { Bananugg } \\
\text { et }\end{array}$ & $\begin{array}{l}\text { Banana } \\
\text { (Noun) }\end{array}$ & $\begin{array}{l}\text { Nugget } \\
\text { (Noun) }\end{array}$ & \\
\hline 2 & Beefbac & $\begin{array}{l}\text { Beef } \\
\text { (Noun) }\end{array}$ & $\begin{array}{l}\text { Bacon } \\
\text { (Noun) }\end{array}$ & \\
\hline 3 & $\begin{array}{l}\text { Booliciou } \\
\mathrm{S}\end{array}$ & $\begin{array}{l}\text { Boo } \\
\text { (Noun) }\end{array}$ & $\begin{array}{l}\text { Delicious } \\
\text { (Adj) }\end{array}$ & \\
\hline 4 & $\begin{array}{l}\text { Burger } \\
\text { King }\end{array}$ & $\begin{array}{l}\text { Hamburger } \\
\text { (Noun) }\end{array}$ & $\begin{array}{l}\text { King } \\
\text { (Noun) }\end{array}$ & \\
\hline 5 & Cebowl & $\begin{array}{l}\text { Rice } \\
\text { (Noun) }\end{array}$ & $\begin{array}{l}\text { Bowl } \\
\text { (Noun) }\end{array}$ & \\
\hline 6 & $\begin{array}{l}\text { Coffeeden } \\
\text { tial }\end{array}$ & $\begin{array}{l}\text { Coffee } \\
\text { (Noun) }\end{array}$ & $\begin{array}{l}\text { Incidenta } \\
1 \\
(\text { Noun })\end{array}$ & \\
\hline 7 & $\begin{array}{l}\text { Dancow } \\
\text { Nutrigold }\end{array}$ & $\begin{array}{l}\text { Nutrition } \\
\text { (Noun) }\end{array}$ & $\begin{array}{l}\text { Gold } \\
\text { (Noun) }\end{array}$ & \\
\hline 8 & Frestea & $\begin{array}{l}\text { Fresh } \\
\text { (Adjective) }\end{array}$ & $\begin{array}{l}\text { Tea } \\
\text { (Noun) }\end{array}$ & \\
\hline 9 & Fullo & $\begin{array}{l}\text { Full } \\
\text { (Adjective) }\end{array}$ & $\begin{array}{l}\text { Chocolat } \\
\mathrm{e} \\
\text { (Noun) }\end{array}$ & \\
\hline 10 & Gooma & $\begin{array}{l}\text { Goo } \\
\text { (Noun) }\end{array}$ & $\begin{array}{l}\text { Matcha } \\
\text { (Noun) }\end{array}$ & \\
\hline 11 & Happytos & $\begin{array}{l}\text { Happy } \\
\text { (Adj) }\end{array}$ & $\begin{array}{l}\text { Tortilla } \\
\text { (Noun) }\end{array}$ & $\begin{array}{l}\text { Chips } \\
\text { (Noun) }\end{array}$ \\
\hline 12 & L-Men & $\begin{array}{l}\text { Leverage } \\
\text { (Noun) }\end{array}$ & $\begin{array}{l}\text { Men } \\
\text { (Noun) }\end{array}$ & \\
\hline 13 & $\begin{array}{l}\text { Lotte } \\
\text { Chocopie }\end{array}$ & $\begin{array}{l}\text { Charlotte } \\
\text { (Noun) }\end{array}$ & $\begin{array}{l}\text { Chocolat } \\
\mathrm{e} \\
\text { (Noun) }\end{array}$ & $\begin{array}{l}\text { Pie } \\
\text { (Noun) }\end{array}$ \\
\hline 14 & Mocktails & $\begin{array}{l}\text { Mock } \\
\text { (Adjective) }\end{array}$ & $\begin{array}{l}\text { Cocktails } \\
\text { (Noun) }\end{array}$ & \\
\hline 15 & $\begin{array}{l}\text { Nutriboot } \\
\mathrm{S}\end{array}$ & $\begin{array}{l}\text { Nutrition } \\
\text { (Noun) }\end{array}$ & $\begin{array}{l}\text { Boots } \\
\text { (Noun) }\end{array}$ & \\
\hline 16 & $\begin{array}{l}\text { Nutrifood } \\
\text { S }\end{array}$ & $\begin{array}{l}\text { Nutrition } \\
\text { (Noun) }\end{array}$ & $\begin{array}{l}\text { Foods } \\
\text { (Noun) }\end{array}$ & \\
\hline 17 & $\begin{array}{l}\text { Oxtail } \\
\text { Soup }\end{array}$ & $\begin{array}{l}\text { Ox } \\
\text { (Noun) }\end{array}$ & $\begin{array}{l}\text { Cocktail } \\
\text { (Noun) }\end{array}$ & \\
\hline 18 & Pancious & $\begin{array}{l}\text { Pan } \\
\text { (Noun) }\end{array}$ & $\begin{array}{l}\text { Delicious } \\
\text { (Adj) }\end{array}$ & \\
\hline 19 & Panchos & $\begin{array}{l}\text { Pan } \\
\text { (Noun) }\end{array}$ & $\begin{array}{l}\text { Chips } \\
\text { (Noun) }\end{array}$ & $\begin{array}{l}\text { Potatoe } \\
\text { s } \\
\text { (Noun) }\end{array}$ \\
\hline 20 & Pejoy & $\begin{array}{l}\text { Perfect } \\
\text { (Adjective) }\end{array}$ & $\begin{array}{l}\text { Joy } \\
\text { (Noun) }\end{array}$ & \\
\hline 21 & Piebis & $\begin{array}{l}\text { Pie } \\
\text { (Noun) }\end{array}$ & $\begin{array}{l}\text { Biscuit } \\
\text { (Noun) }\end{array}$ & \\
\hline 22 & Poterich & $\begin{array}{l}\text { Potatoes } \\
\text { (Noun) }\end{array}$ & $\begin{array}{l}\text { Rich } \\
\text { (Adj) }\end{array}$ & \\
\hline
\end{tabular}




\begin{tabular}{|c|c|c|c|}
\hline 23 & Ricola & $\begin{array}{l}\text { Rich } \\
\text { (Adjective) }\end{array}$ & $\begin{array}{l}\text { Cola } \\
\text { (Noun) }\end{array}$ \\
\hline 24 & $\begin{array}{l}\text { Sensacool } \\
\mathrm{S}\end{array}$ & $\begin{array}{l}\text { Sensation } \\
\text { (Noun) }\end{array}$ & $\begin{array}{l}\text { Cools } \\
\text { (Noun) }\end{array}$ \\
\hline 25 & Scaries & $\begin{array}{l}\text { Scare } \\
\text { (Noun) }\end{array}$ & $\begin{array}{l}\text { Series } \\
\text { (Noun) }\end{array}$ \\
\hline 26 & Smarties & $\begin{array}{l}\text { Smart } \\
\text { (Adjective) }\end{array}$ & $\begin{array}{l}\text { Series } \\
\text { (Noun) }\end{array}$ \\
\hline 27 & Strepsils & $\begin{array}{l}\text { Strep } \\
\text { (Noun) }\end{array}$ & $\begin{array}{l}\text { Sills } \\
\text { (Noun) }\end{array}$ \\
\hline 28 & $\begin{array}{l}\text { Thaitea } \\
\text { Tune }\end{array}$ & $\begin{array}{l}\text { Thailand } \\
\text { (Noun) }\end{array}$ & $\begin{array}{l}\text { Tea } \\
\text { (Noun) }\end{array}$ \\
\hline 29 & Yogo & $\begin{array}{l}\text { Yogurt } \\
\text { (Noun) }\end{array}$ & $\begin{array}{l}\text { Go } \\
\text { (Noun) }\end{array}$ \\
\hline
\end{tabular}

*The blue color is the splinter word

The 29 data in the table can be categorized as complex blending. The characteristic of complex blending is combining one of the full words (without truncating the letter of the word), either it is placed in the first source word or the second. The first source word mixes with the second source words or the third source word with the splinter word. The splinter word can be placed in the first or second word randomly.

While the splinter word can be said as the truncated portions of words (Shaw, 2013). Soudek in Fandrych (Rini \& Moehkardi, 2019) divides the splinter into two terms, initial splinter and final splinter. The initial splinter refers to the first or second element of the blend for the former, and the last splinter refers to the second element of the blend for the latter. Danks (Rini \& Moehkardi, 2019) argues that the term splinter, part, and bits are synonymous and both are generally used in the blends. Other characteristics or techniques in blending cover mixing 2 or 3 words, fusion, cutting words (clipping), merging, shortening, and removal words.

The tabulated data uses the technique of clipping by splinting or truncating one or more letters in one of the source words such as in the portmanteau word of 'Oxtail' (Ox + Cocktail). The letter in the source word 'Ox' is still retained entirely. The source word 'Cocktail" is used as a clipping technique. O "Grady \& Guzman in (Sundari, 2008) state clipping is shortening a polysyllabic word. It removes one or more syllables. (Algeo, 2010) adds that the term of a clipped form is a shortening of a longer word. Data in table 1 shows that many blending of foods and beverages are found. Those 29 words are considered as the wordplay (blending or the portmanteau word is the phenomenon of wordplay. It is the core and stands for the blending term (e.g., Quirk et al.; Fandrych; Schmid; Alm-Arvius; Fábregas \& Scalise; Kjellander, 2015). Their combinations bring a unique sound and word based on two or three combined words to get the new vocabulary and new meaning.
The next discussion shows the result of the second types of blending as tabulated below:

Table 2 Back Clipped Word

\begin{tabular}{|l|l|l|l|}
\hline \multirow{2}{*}{ No } & \multirow{2}{*}{$\begin{array}{c}\text { The } \\
\text { Portmantea } \\
\text { u Word }\end{array}$} & $\begin{array}{c}\text { Blending Formation } \\
\text { Source of } \\
\text { the } \mathbf{1}^{\text {st }} \\
\text { Word }\end{array}$ & $\begin{array}{c}\text { Source of } \\
\text { the 2 } \\
\text { Word }\end{array}$ \\
\hline 1 & Cocoyo & $\begin{array}{l}\text { Coconut } \\
\text { (Noun) }\end{array}$ & $\begin{array}{l}\text { Yogurt } \\
\text { (Noun) }\end{array}$ \\
\hline 2 & Delico & $\begin{array}{l}\text { Delicious } \\
\text { (Adj) }\end{array}$ & $\begin{array}{l}\text { Corner } \\
\text { (Noun) }\end{array}$ \\
\hline 3 & Frugra & $\begin{array}{l}\text { Fruit } \\
\text { (Noun) }\end{array}$ & $\begin{array}{l}\text { Granola } \\
\text { (Noun) }\end{array}$ \\
\hline 4 & Japota & $\begin{array}{l}\text { Japan } \\
\text { (Noun) }\end{array}$ & $\begin{array}{l}\text { Potatoes } \\
\text { (Noun) }\end{array}$ \\
\hline 5 & $\begin{array}{l}\text { V-Soy } \\
\text { Cocoa }\end{array}$ & $\begin{array}{l}\text { Vitamin } \\
\text { (Noun) }\end{array}$ & $\begin{array}{l}\text { Soya } \\
\text { (Noun) }\end{array}$ \\
\hline
\end{tabular}

*The blue color is the splinter word

Back Clipped word is part of the second type of blending process. It is formed by combining the final splinter in the last syllable of the source word. The splinter can be applied in one or two source words. The example, in the word 'Cocoyo', the combination is made from 'Coconut + Yogurt'. Both source words are shortened in the final splinter, and the word parts are combined into new blending (Cocoyo).

In this case, 5 data show their blending by mixing two source words, and each letter of the word is cut in the back. So it just leaves the head letter in front of each source word and combines with the second one. The number of shorted letters or short words is irregular. It means the process of cutting or removing depends on the wishes, likes, and thoughts of the creators of the blending to make the portmanteau word useful and suited to be heard. So those practices can be applied to name their product.

Table 3 Back and Fore Clipped Word

\begin{tabular}{|c|l|l|l|}
\hline \multirow{2}{*}{ No } & \multirow{2}{*}{$\begin{array}{c}\text { The } \\
\text { Portmanteau } \\
\text { Word }\end{array}$} & $\begin{array}{l}\text { Blending Formation } \\
\text { Source of } \\
\text { the } \\
\text { Word }\end{array}$ & $\begin{array}{l}\text { Source of } \\
\text { the 2 } \\
\text { Word } \\
\text { Word }\end{array}$ \\
\hline 1 & Brunch Camba & $\begin{array}{l}\text { Breakfast } \\
\text { (Noun) }\end{array}$ & $\begin{array}{l}\text { Lunch } \\
\text { (Noun) }\end{array}$ \\
\hline 2 & Delfi Nockers & $\begin{array}{l}\text { Nougat } \\
\text { (Noun) }\end{array}$ & $\begin{array}{l}\text { Crackers } \\
\text { (Noun) }\end{array}$ \\
\hline 3 & Mizone & $\begin{array}{l}\text { Mineral } \\
\text { (Adjective) }\end{array}$ & $\begin{array}{l}\text { Ozone } \\
\text { (Noun) }\end{array}$ \\
\hline 4 & Twix & $\begin{array}{l}\text { Twin } \\
\text { (Adjective) }\end{array}$ & $\begin{array}{l}\text { Mix } \\
\text { ( Noun) }\end{array}$ \\
\hline 5 & Vegips & $\begin{array}{l}\text { Vegetable } \\
\text { (Noun) }\end{array}$ & $\begin{array}{l}\text { Chips } \\
\text { (Noun) }\end{array}$ \\
\hline
\end{tabular}

*The blue color is the splinter word 
The next type of blending process is the fore clipped word. As the name suggested, this third type of blending process is formed by shorting and removing the letter's head at the beginning of the source word. The removing letter can be more than one. The researchers do not find this third category in each specific case, but we only join the back and fore clipped words in the tabulated data. They are 5 data that can be involved in this formation and the portmanteau words only consist of two source words. The portmanteau word process is formed by fusing the two source words and cutting each letter in the fore or back word.

The research assumption on sticking the fore and back clipped word into the new word or blending is based on (Hosseinzade, 2014) argument. He exemplifies the portmanteau word 'navicert' (navigation + certificate) are formed from compound and clipping. It shows that both halves of a compound are clipped. In this case, he says that it is difficult to know whether the resultant formation should be treated as clipping or as a blend because the border between the two types is not always clear. Based on that argument, blending is similar to compounding. The blending word involves the combination of two separate forms to produce a single new term. Then, the back and fore clipped word can be applied in the blending process as the example of the portmanteau word 'Vegips,' and it is formed from the two mixing words in the first source word 'Vegetable' and the second source word 'Chips'. The first source word is splinted in its letter in the back, and the second source word is splinted in the head, and that proses are applied to 5 data.

Table 4 Phonemic Overlapping and Clipping

\begin{tabular}{|c|c|c|c|c|}
\hline \multirow[b]{2}{*}{ No } & \multirow[b]{2}{*}{$\begin{array}{c}\text { The } \\
\text { Portmante } \\
\text { au Word }\end{array}$} & \multicolumn{3}{|c|}{ Blending Formation } \\
\hline & & $\begin{array}{c}\text { Source } \\
\text { of the } 1^{\text {st }} \\
\text { Word }\end{array}$ & $\begin{array}{l}\text { Source } \\
\text { of the } \\
2^{\text {nd }} \\
\text { Word }\end{array}$ & $\begin{array}{c}\text { Source } \\
\text { of the } \\
\mathbf{3}^{\text {rd }} \\
\text { Word }\end{array}$ \\
\hline 1 & Biskitop & $\begin{array}{l}\text { Biscuit } \\
\text { (Noun) } \\
\text { \'bi-skət। }\end{array}$ & \begin{tabular}{l} 
Stick \\
(Noun) \\
''stik\} & 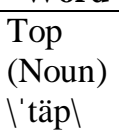 \\
\hline 2 & Bobal & $\begin{array}{l}\text { Boba } \\
\text { (Noun) } \\
\text { \'bō-bə \} } & \begin{array}{l}\text { Ball } \\
\text { (Noun) } \\
\text { \'ból \} } & \\
\hline 3 & \text { Chacha } & \begin{array}{l}\text { Chocolat } \\
\mathrm{e} \\
\text { (Noun) } \\
\text { l'chä- } \\
\text { k(ə-)lət, } \\
\text { 'chö-। }\end{array} & \text { 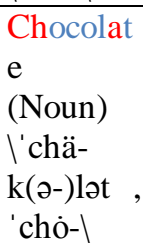 } & \\
\hline 4 & \text { Chicking } & \begin{array}{l}\text { Chicken } \\
\text { (Noun) } \\
\text { l'chi-kn, } \\
\text { sometim }\end{array} & \begin{array}{l}\text { King } \\
\text { (Noun) } \\
\text { \'kin\} } & \\
\hline\end{array}\end{array}\end{array}$
\end{tabular}
\end{tabular}

\begin{tabular}{|c|c|c|c|c|}
\hline & & es $-k^{\curvearrowright} \eta \backslash$ & & \\
\hline 5 & Chizmill & $\begin{array}{l}\text { Cheese } \\
\text { (Noun) } \\
\text { ''chēzl }\end{array}$ & $\begin{array}{l}\text { Mill } \\
\text { (Noun) } \\
\text { l'mil }\end{array}$ & \\
\hline 6 & Crunches & \begin{tabular}{l} 
Crunchy \\
(Adj) \\
\'krən- \\
chē \} & $\begin{array}{l}\text { Cheese } \\
\text { (Noun) } \\
\text { ''chēzl }\end{array}$ & \\
\hline 7 & FlavaOurs & $\begin{array}{l}\text { Flavor } \\
\text { (Noun) } \\
\text { ''flā-vər\} } & \begin{array}{l}\text { Ours } \\
\text { (Poss } \\
\text { Adj) } \\
\text { ' 'aù(-ə)rz } \\
\text {, ärz\} } & \\
\hline 8 & \text { Gogocha } & \begin{array}{l}\text { Go } \\
\text { (Verb) } \\
\text { \'gō \} } & \begin{array}{l}\text { Go } \\
\text { (Verb) } \\
\text { \'gō \} } & \begin{array}{l}\text { Matcha } \\
\text { (Noun) } \\
\text { l'mä- } \\
\text { chə } \\
\text { 'ma-। }\end{array} \\
\hline 9 & \begin{array}{l}\text { Krip Krip } \\
\text { Tortilla }\end{array} & \begin{array}{l}\text { Crispy } \\
\text { (Adj)s } \\
\text { ''kri-spēl }\end{array} & \begin{array}{l}\text { Crispy } \\
\text { (Adj) } \\
\text { 'kri-spēl }\end{array} & \\
\hline 10 & \begin{array}{l}\text { Koko } \\
\text { Krunch }\end{array} & \begin{array}{l}\text { Koko } \\
\text { (Noun) } \\
\text { l'kō(,)kō } \\
\text { । }\end{array} & \begin{array}{l}\text { Crunchy } \\
\text { (Adj) } \\
\text { ''krən- } \\
\text { chē \} } & \\
\hline 11 & \text { Mayumi } & \begin{array}{l}\text { Mayonna } \\
\text { ise } \\
\text { (Noun) } \\
\text { l'mā-ə- } \\
\text { 'nāz } \\
\text { 'mā-ə- } \\
\text { 'nāz, } \\
\text { 'ma-,nāz, } \\
\text { 'mā-,nāz } \\
\text { । }\end{array} & \begin{array}{l}\text { Yummy } \\
\text { (Adj) } \\
\text { l'yə-mēl }\end{array} & \\
\hline 12 & \text { Oatsy } & \text { 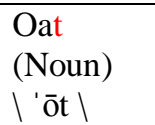 } & \begin{array}{l}\text { Testy } \\
\text { (Adj) } \\
\text { ''te-stē } \backslash\end{array} & \\
\hline 13 & \text { Pureal } & \begin{array}{l}\text { Pure } \\
\text { (Adj) } \\
\text { l'pyü\} } & \begin{array}{l}\text { Real } \\
\text { (Adverb) } \\
\text { ''rē(-ə)l\} } & \\
\hline 14 & \text { Richiken } & \text { 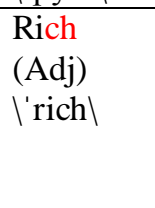 } & \text { 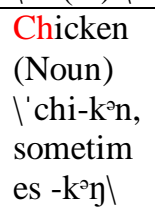 } & \\
\hline 15 & \text { Snackers } & \begin{array}{l}\text { Snack } \\
\text { (Noun) } \\
\text { \'snak \} } & \begin{array}{l}\text { Crackers } \\
\text { (Noun) } \\
\text { \'kra- } \\
\text { kərz\} } & \\
\hline 16 & \text { Snackit } & \begin{array}{l}\text { Snack } \\
\text { (Noun) } \\
\text { \'snak \} } & \text { 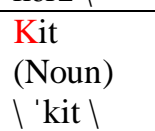 } & \\
\hline 17 & \text { Twisko } & \begin{array}{l}\text { Twist } \\
\text { (Verb) } \\
\text { \'twist }\end{array} & \begin{array}{l}\text { Corn } \\
\text { (Noun) } \\
\text { l'kỏrn\ }\end{array} & \\
\hline 18 & \text { Yoforia } & \begin{array}{l}\text { Yogurt } \\
\text { (Noun) } \\
\text { l'yō-gərt } \\
\text { l }\end{array} & \begin{array}{l}\text { Euphoria } \\
\text { (Adj) } \\
\mid \text { yü-' för- } \\
\overline{\mathrm{e}}-2 \mid\end{array} & \\
\hline\end{array}\end{array}\end{array}\end{array}\end{array}\end{array}\end{array}\end{array}\end{array}\end{array}$
\end{tabular}
\end{tabular}


*The blue color is the splinter word. The red color is an overlapping of the sound of the letter, either its grapheme or phoneme.

The last type is phonological overlapping and clipping. This type includes the terms of the mixing process between cutting words (clipping), shortening the source word, and removing words either it's sound of letters or syllable. It emphasizes on the overlapping of the sound and the same syllable in both combinations. Usually, the same sound of the syllable in the first source word meets with the portion of the second source word. Thus the fusing of the sound from the two source words is overlapping to each other. The term of the same sound is devoted to a class of similar sounds. It is used to call a phoneme (Algeo, 2010).

Algeo comments that blending sometimes takes place the insertion of one form into another. The insertion can be a form of possible overlapping of segments (Hosseinzade, 2014). The example is in the word 'Chicking'. This portmanteau plays word on the two fusions of the source words 'Chicken' and 'King'. When the first source word 'Chicken' is shortened (two syllables in the back of its word), the first source word 'Chick-en' becomes the splinter word 'Chick'.

Meanwhile, the second source word, 'King,' is combined. The combination of two source words plays an overlapping sound, 'Chickking'. So it can be said that this combination affects the double sound of the same syllable ' $\mathrm{K}$ ' (It is called phonemic overlapping). To make the portmanteau sound easy to hear, the omitting must be adjusted to one of the same syllable ' $\mathrm{K}$ '. It is clear that 'Chicking' is the process that involves clipping and phonemic overlapping because it has the same sound as the letter.

Other cases can be displayed by the relation of grapheme and sound (Phonemic). Gries in (Čolić, 2015) asserts that blending involves creating a new lexeme by combining two or more word sources in which part of one of the source word is shortened or reduced, and some have phonemic or graphemic overlapping forms of source words. The example is in the portmanteau word 'Chizmill'. It is made of combining the first source word 'Cheese' and the second source word 'Mill'. The sound of the first source word 'Cheese' is changed into its phonemic ' $\backslash$ 'chēz \, and it is written as heard by its sound (graphemic). Afterward, the first source word combines with the second splinter word.

They are 18 data that can be grouped into this classification. Despite that finding, at the same time, they are types of combinations that join together with other types. (The portmanteau word can be a complex clipped word or back clipped word and overlapping). It is shown in the word 'Chicking', on the one hand, it can be put into phonemic overlapping. On the other hand, the technique of complex clipped words can be used from the second source word 'King' when combined with the first source word 'Chic'. The second source word still keeps the word entirely without omitting or removing its letter.

The last notion is it is easy to mix the two source words and form new blendings like 'Chizmill' and 'Chicking', but the combination is followed by the creators of blending who have the right to make it and appropriate it to their product. The creators of blending also have their background to coin the new word either based on the relation to their culture, education, thought, and business or creating blending word just to have fun as said by (Colic 2015) that the creators of the portmanteau word find the meaning of the new word more transparent, exact, and evident because they are familiar with the meanings of its constituents using the semantic technique.

\section{How the culture contained in the portmanteau words (the English foods and beverages) is revealed?}

The second question of this research is questioning the cultural words contained in the source word of the portmanteau, particularly in the name or brand of foods and beverages. The answer can be gained from the origins of the source word and their combination, as shown in the attached tables:

Table 5 the Origins of the Source Word

\begin{tabular}{|l|l|l|l|}
\hline No & $\begin{array}{l}\text { The Source } \\
\text { Word }\end{array}$ & $\begin{array}{l}\text { Word } \\
\text { Class }\end{array}$ & $\begin{array}{l}\text { The Origin of the } \\
\text { Word }\end{array}$ \\
\hline 1 & Bacon & Noun & $\begin{array}{l}\text { From Germany and } \\
\text { French }\end{array}$ \\
\hline 2 & Boba & Noun & $\begin{array}{l}\text { Chinese from } \\
\text { Bubble Tea' }\end{array}$ \\
\hline 3 & Boo & $\begin{array}{l}\text { Adjectiv } \\
\text { e }\end{array}$ & From French \\
\hline 4 & Chocolate & Noun & From Spanish \\
\hline 5 & Coffee & Noun & From Turkish \\
\hline 6 & Euphoria & Adj & From Greek \\
\hline 7 & Flavor & Noun & From Latin \\
\hline 8 & Hamburger & Noun & From Germany \\
\hline 9 & Matcha & Noun & From Japan \\
\hline 10 & Mayonnaise & Noun & From French \\
\hline 11 & Nougat & Noun & From French \\
\hline 12 & Potato & Noun & From Spanish \\
\hline 13 & Soya & Noun & $\begin{array}{l}\text { via Dutch 'Soja' } \\
\text { from Japan }\end{array}$ \\
\hline 14 & Tortilla & Noun & From Spanish \\
\hline 15 & Whey & Noun & From German \\
\hline 16 & Yogurt & Noun & From Turkish \\
\hline
\end{tabular}


All the tabulated data present the origins of the source word, and they are summed up from data in tables 1, 2, 3, and 4. Table 5 consists of 16 English borrowed words. The origins of the source words come from spices or food ingredients. The Spanish word consists of 3 words. Turkish, French, and Japan consist of 2 words. Chinese, German, Latin, and Greek consist of 1 word in each source word.

Those source words can be seen from the cultural views. To see the culture can be looked at the origins of the source words, which denote the food and beverage product's culture. The composing of the herbs and ingredients' names in English blending relates to the borrowed word. According to Fromkin et al., to borrow the words from other languages is needed because it can add a source of the new words (Fatmaway \& Anggraini, 2019). This technique is the most common source practiced in English as the process of adding the new source word (Yule in Fatmaway \& Anggraini, 2019). In this case, linguistic and cultural relations are seen through 16 borrowing words. The portmanteau words of foods and beverages refer to linguistics and the culture that shows where the word comes from and ties with its characters through the experience in the cultural origins.

In this description, cultural food and beverage are experienced in English names. The experience of taste, style, and brand is revealed and represented in the borrowed word, for example, in the word 'Oxtail' in table $1(\mathrm{Ox}+$ Cocktail). The fact proves that the English name of $(\mathrm{Ox}+$ Cocktail) has a food style coming from English. This term can be used as food made or comes from a foreign seeing from its name, but actually, it is wrapped in Indonesian taste because it is sold in Indonesia. It is sold and made in Indonesia, but it also has a composition of ingredients or spices formulated in Indonesian cuisine. So this brand brings a mixture of two cultures of Indonesia and the English term. This experience happens in other blending words borrowed from other languages such as Spanish, Turkish, French, Japan, Chinese, German, Latin, and Greek. This happens because there is a lack of English vocabulary to call something that does not exist in an English country or culture. Looking into another description in table 5, the word 'Boba' is borrowed and existed in the English dictionary. Boba comes from Chinese to indicate a black bubble drink (black pearl) with new components such as a mixture of cold fresh milk, caramel palm sugar, and tapioca pearls. The word 'Boba' already exists in China since 1987. It represents people drinking milk tea with traditional milk butter and ice into a cocktail shaker (a shaker glass). This method changed the tradition of drinking tea in China, which usually uses green tea in a cup, then this phenomenon is raised and spread globally (Cong, 2016). So from both explanations can be concluded that borrowing word is not only a form of linguistic or part of the word-formation, but it also has a relationship with a culture where the foods and beverages are made and placed.

\section{CONCLUSION}

They are four types of blending formation or process found in this research: Complex clipped word, back clipped word, fore, and back the clipped word, and phonemic overlapping and clipping. Those are commonly used to make the new term of standard and cannot be found in the dictionary. Meanwhile, the culture of the portmanteau word in the name or brand of food and beverages is mostly composed of herbs and ingredients of the 13 borrowed words such as Spanish, Japan, Turkish, German, French, Latin, Chinese, and Greek in which those 13 borrowed words bring the culture of the origin.

The researchers found 2 or 3 combinations of the source word, and most of the portmanteau words consist of two combined words. Despite that result, they are only three portmanteau words consisting of three source words. However, some blends are composed of more than three source words for some rare cases. After all discussion, it can be concluded that using types of blending in foods and beverages is easy to recognize the meaning of its source words and its portmanteau words, significantly if the people or creators understand well the structure, types, and word class of blending. Blending creators' involvement in making specific meanings is based on their senses and distributes it into a linguistic way, either intentional or unintentional.

As continual research, the development of the blending concept in English food and drinks in Indonesia can be investigated by looking at or analyzing the types of blending and relating them to acronyms, derivations, clipping, and compounding of the word-formation in morphology. In turn, this analysis is not enough to be reading. There is a need for continuing future research to support and create a new reference for marketing the blending product. So this research will be continued getting the topic of English blending on food and its relation to marketing, mainly it discusses the strategy of marketing English foods and beverages through the concept of blending based on language in advertising. The resulting process is used to arouse, attract, identify, mobilize together, and combine messages comparatively to consumers of foods and beverages. Another research can be studied on what the English food and beverage brand represent using the concept of vogue words as conducted by Klaudia Bednárová-Gibová in fashion magazines as the previous research.

Further, the research can be conducted by 
looking at the term of echoic or onomatopoeic, symbolic, and hypercorrection in food and beverage names. Another researcher can investigate the blending formation through children's language, slang language, or language used by young people, gender, etc. Those researches are benefits to prove the popularity of English or Indonesian blending seen from the largest number of users in Indonesia. Additionally, because English in the names or brands of food and beverage products is attractive, memorable, classy, tasty, and easy to say or to hear, it can be investigated to know its relation with prestige and pride of social status and class.

\section{ACKNOWLEDGMENTS}

This small scale research is part of the output which is grateful to be published in the reputable journal because of the Ministry of Research funds this research, Technology and Higher Education of Republic Indonesia, as a form of beginner lecturer research entitled "Pengembangan Konsep Blending Pada Nama Makanan dan Minuman: Sudut Pandang Kajian Bahasa dan Budaya". Thus, this research is not only expected to be a reading that can add knowledge, enrich methods, find problems and solutions, and develop theories through the formation of new English words (blending) but also the results of this study are expected to be continued and developed into largescale research involving two fields of language studies and marketing management to produce findings of the sales strategies for food products in Indonesia.

\section{REFERENCE}

Algeo, J. (2010). The Origins And Development Of The English Language (6th Editio; Megan Garvey; Rebekah Matthews, Ed.). Retrieved from

https://books.google.com/books?hl=en \&lr=\&id =1aJ9U9nrjqsC\&oi=fnd\&pg=PP1\&dq=The+O rigins+And+Development+Of+The+English $+\mathrm{L}$ anguage \&ots $=$ ZxNdQitwq\&sig=Qz_A1IAUIBFzO1vrN2ebJI8nHCs.

Čolić, A. M. (2015). Word Formation Of Blends. Moustariensia-Journal of Social Sciences and Humanities, (2), 21-36. Retrieved from https://www.researchgate.net/publication/3276 05690_WORD_FORMATION_OF_BLENDS.

Cong, S. C. (2016). Fill My Cup Half Full: Boba Stories (University of California). Retrieved from https://escholarship.org/uc/item/461210j5
Fajrin, E. (2017). An Analysis Of Word Formation In Jargon Used By Xiaomi Faculty Of Humanities (Universitas Islam Negeri Maulana Malik Ibrahim). Retrieved from https://core.ac.uk/download/pdf/160461861.pdf

Fatmaway, Riryn \& Anggraini, P. A. (2019). An Analysis Of English Word Formation Processes In Beats Apart Novel By Alanda Kariza And Kevin Aditya. E-Link Journal, 6(01), 164-182.

Giyatmi; Wijayava; Arumi. (2018). Blending Sebuah Alternatif Dalam Penamaan Makanan Dan Minuman Ringan. Adabiyyāt: Jurnal Bahasa Dan Sastra, II(2), 156-180. Retrieved from https://www.google.com/url?sa=t\&rct=j\&q=\& esrc $=$ s\&source $=$ web\& $c d=12 \&$ cad $=r j a \& u a c t=8$ \&ved=2ahUKEwiBnb2-

477oAhWJe30KHagXDNMQFjALegQIAxAB \&url=https\%3A\%2F\%2Fwww.researchgate.net \%2Fpublication\%2F334305770_BLENDING_ SEBUAH_ALTERNATIF_DALAM_PENAM AAN_MAKANAN_DAN_MINUMAN_RING AN\&usg=AOvVaw24ArmNL542p7gf3BVQfS 95

Hosseinzade, N. M. (2014). New Blend In the English Language. International Journal of English Language and Linguistics Research, 2(2), 15-26. Retrieved from www.eajournals.org

Kjellander, D. (2015). Beauty And The Blend (Stockholm University). Retrieved from http://www.divaportal.org/smash/record.jsf?pid=diva2:821138

Komara, C. (2015). Analisis Struktur Lexical Blend Nama Produk Waralaba Indonesia. Universitas Pendidikan Indonesia. Konferensi Linguistik Tahunan Atma Jaya 13, 1-8. Retrieved from https://www.google.com/url?sa=t\&rct=j\&q=\& esrc $=$ s\&source $=$ web $\& c d=17 \&$ ved $=2$ ahUKEwi Bnb2-

477oAhWJe30KHagXDNMQFjAQegQIBxAB \&url=https $\% 3 \mathrm{~A} \% 2 \mathrm{~F} \% 2 \mathrm{Fosf} .10 \% 2 \mathrm{Fvyag} 2 \% 2 \mathrm{~F}$ download\&usg=AOvVaw1vbOPJgpMieK5VhbRPtSY

Lestari, desi indah. (2017). Pemakaian Bahasa Pada Iklan Produk Minuman Di Televisi Dan Implikasinya Dalam Pembelajaran Menulis Slogan Dan Poster Di Sekolah Menengah Pertama (Universitas Lampung Bandarlampung). Retrieved from http://digilib.unila.ac.id/26339/

Purwani, N. (2013). Penggunaanbahasa Inggris Dalam Iklanmakanan Dan Minuman: Peluang Ataukah Ancaman? International Seminar 
"Language Maintenance and Shift III", Semarang, July 2-3, 2013, 346-350. Retrieved from http://eprints.undip.ac.id/54466/

Rini, R., \& Moehkardi, D. (2019). English Blends in Indonesian Context : Their Formation Processes and Meanings. Humaniora, 31(1), 21-32. Retrieved from https://journal.ugm.ac.id/jurnalhumaniora/article/view/40374

Shaw, K. (2013). Head Faithfulness In Lexical Blends: A Positional Approach To Blend Formation (the University of North Carolina). Retrieved from http://linguistics.unc.edu/files/2011/11/5240.pd f

Sundari, W. (2008). Proses Pembentukan NamaNama Menu Makanan Berbahasa Inggris. Universitas Dipenogoro. 